\title{
Cloning, Purification, and Characterization of a $\beta$-Carbonic Anhydrase from Malassezia restricta, an Opportunistic Pathogen Involved in Dandruff and Seborrheic Dermatitis
}

\author{
Sonia Del Prete ${ }^{1}$, Daniela Vullo ${ }^{2}$, Cynthia Ghobril ${ }^{3}$, Julien Hitce ${ }^{3}$, Cécile Clavaud ${ }^{3}$, \\ Xavier Marat ${ }^{3}$, Clemente Capasso ${ }^{1, * \mathbb{D}}$ and Claudiu T. Supuran ${ }^{2, * \mathbb{D}}$ \\ 1 Istituto di Bioscienze e Biorisorse, CNR, Via Pietro Castellino 111, 80131 Napoli, Italy; \\ sonia.delprete@ibbr.cnr.it \\ 2 Dipartimento Neurofarba, Sezione di Scienze Farmaceutiche e Nutraceutiche, Università degli Studi di Firenze, \\ Via U. Schiff 6, 50019 Sesto Fiorentino, Florence, Italy; daniela.vullo@unifi.it \\ 3 L'Oréal Research and Innovation, 93601 Aulnay-sous-Bois, France; cynthia.ghobril@rd.loreal.com (C.G.); \\ julien.hitce@rd.loreal.com (J.H.); cecile.clavaud@rd.loreal.com (C.C.); xavier.marat@rd.loreal.com (X.M.) \\ * Correspondence: clemente.capasso@ibbr.cnr.it (C.C.); claudiu.supuran@unifi.it (C.T.S.)
}

Received: 3 May 2019; Accepted: 15 May 2019; Published: 17 May 2019

check for updates

\begin{abstract}
The cloning, purification, and initial characterization of the $\beta$-carbonic anhydrase (CA, EC 4.2.1.1) from the genome of the opportunistic pathogen Malassezia restricta (MreCA), which a fungus involved in dandruff and seborrheic dermatitis (SD), is reported. MreCA is a protein consisting of 230 amino acid residues and shows high catalytic activity for the hydration of $\mathrm{CO}_{2}$ into bicarbonate and protons, with the following kinetic parameters: $\mathrm{k}_{\mathrm{cat}}$ of $1.06 \times 10^{6} \mathrm{~s}^{-1}$ and $\mathrm{k}_{\mathrm{cat}} / \mathrm{K}_{\mathrm{M}}$ of $1.07 \times 10^{8} \mathrm{M}^{-1} \mathrm{~s}^{-1}$. It is also sensitive to inhibition by the sulfonamide acetazolamide $\left(\mathrm{K}_{\mathrm{I}}\right.$ of $\left.50.7 \mathrm{nM}\right)$. Phylogenetically, MreCA and other CAs from various Malassezia species seem to be on a different branch, distinct from that of other $\beta$-CAs found in fungi, such as Candida spp., Saccharomyces cerevisiae, Aspergillus fumigatus, and Sordaria macrospora, with only Cryptococcus neoformans and Ustilago maydis enzymes clustering near MreCA. The further characterization of this enzyme and the identification of inhibitors that may interfere with its life cycle might constitute new strategies for fighting dandruff and SD.
\end{abstract}

Keywords: carbonic anhydrase; Malassezia restricta; cloning; enzyme inhibition; acetazolamide

\section{Introduction}

Carbonic anhydrases (CA, EC 4.2.1.1) catalyze the simple but physiologically crucial interconversion of carbon dioxide and water into bicarbonate and protons: $\mathrm{CO}_{2}+\mathrm{H}_{2} \mathrm{O} \rightleftharpoons \mathrm{HCO}_{3}{ }^{-}+$ $\mathrm{H}^{+}$[1-5]. These metalloenzymes are indispensable for maintaining the physiological equilibrium of the dissolved $\mathrm{CO}_{2}, \mathrm{H}_{2} \mathrm{CO}_{3}, \mathrm{HCO}_{3}{ }^{-}$, and $\mathrm{CO}_{3}{ }^{2-}$, which are metabolites essential for the biosynthesis and energy metabolism of organisms [5-9]. Thus, the survival of a microbe will be compromised by restricting the access of a pathogen to these metabolites. Interference with $\mathrm{pH}$ regulation, as well as metabolic pathways connected with the inhibition of CA activity, has begun to be considered for obtaining new anti-infective agents [10-14], in addition to applications of such agents for antitumor therapies [14-17] — the field in which this approach was validated after more than a decade of strenuous research efforts $[6,7,18-21]$. Indeed, the 21st century has been affected by the spread of antibiotic resistance, and consequently, the improvement of the pharmacological arsenal against pathogens is needed [22-26]. Most of the existing antibiotics target a microorganism's cellular functions, such as 
the synthesis of proteins, nucleic acids, cell walls, or folate [27-29]. Generally, the identification of novel drug targets follows criteria pointing to pathogen survival and absence from the human genome [30-32]. Recently, it has been demonstrated that the CA superfamily represents a valuable member of new macromolecules affecting the growth of microorganisms or making them vulnerable to host defense mechanisms [32-34]. Targeting CAs from pathogens belonging to various species of bacteria, fungi, and protozoans may lead to anti-infectives with new mechanisms of action different from the clinically used agents [34-37]. Among the fungal pathogens investigated in detail, Malassezia globosa (MgCA) represents a particular case [38-41], because the $\beta$-CA encoded in the genome of this fungus was shown to be a druggable target [41]. Indeed, several effective in vitro MgCA inhibitors belonging to the sulfonamide type were also shown to have significant antifungal effects in vivo, in an animal model of dandruff [42-44]. Thus, after considering the significant drug resistance problems with azoles and other antifungals [45-49], MgCA was validated as a possible antifungal target.

Recently, it has been demonstrated that, rather than one particular Malassezia sp. being involved, a complex bacterial and fungal equilibrium is involved in dandruff [50-56]. Another Malassezia species, Malassezia restricta is also involved in triggering the disequilibrium between the commensals Cutibacterium acnes (formerly named Propionibacterium acnes) and Staphylococcus sp., both of which contribute to dandruff and seborrheic dermatitis symptoms [50-52,57]. Furthermore, the genome of this pathogen was recently decoded and was published [57], making it possible to search for potential drug targets and the corresponding agents that may interfere with them. For this reason, we decided to investigate the analogous enzyme from $\mathrm{MgCA}$, which should also be present in the genome of $M$. restricta. here, we report on the cloning, purification, and characterization of the $\beta$-CA from the pathogenic fungus, $M$. restricta (MreCA).

\section{Results and Discussion}

\subsection{MreCA Features}

The genome of $M$. restricta contains a region of $690 \mathrm{bp}$ encoding for a polypeptide chain of 230 amino acid residues and is homologous to the $\beta$-CA identified in the genome of M. globosa (MgCA). To show the relevant degree of homology existing between these enzymes, MreCA was aligned with $\mathrm{MgCA}$ and Cryptococcus neoformans CA (Can2) [58,59], as shown in Figure 1.

MreCA contains all the typical features of $\beta$-CAs, including the three residues that are involved in the catalytic mechanism of the enzyme, acting as zinc ligands (two cysteines and one histidine). It also contains amino acid residues, including the catalytic dyad that consists of an aspartate and an arginine, which are involved in the activation of the zinc-coordinated water molecule responsible for nucleophilic attack [38-45,58,59] (Figure 1). To better investigate the relationships between MreCA and the $\beta$-CAs identified in other species, such as insects, plants, fungi, algae, and bacteria, the most parsimonious phylogenetic tree has been constructed (Figure 2), which takes into account all the amino acid substitutions that differentiate $\beta$-CAs from various organisms indicated in Table 1. 


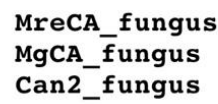

61

$$
\mathrm{Zn} \mathrm{Zn}
$$
MRRCQSSMSTSPPFSRATTDS---------TTDRNASWSQDF ISQQPDTANATRQGQH MPFHAEPLKPSDE IDMDLGHSVAAQKFKEIREVLEGNRYWARKVTSEEPEFMAEQVKGQA : .
$: * *: \ldots:$ : $*$ :

PKVFWIGCSDSRVPESVVCNARPGETFVLRNVANQFHPNDDSAVSATIFAVQATGVEHVIVVGHTSCGGVTAAVNQ PKVFWIGCSDSRVPESVVCNARPGELFVLRNVANOFHLHDDSAVSALTFAVQALGVEHVIVVGHTSCGGVAAAVKO PNFLWIGCADSRVPEVTIMARKPGDVFVQRNVANQFKPEDDSSQALLNYAIMNVGVTHVMVVGHTGCGGCIAAFDQ

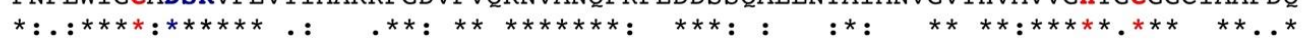

137

AIKEODEDHELPSSSATTRHLTPTTGTARYTRVRVRERNLMSPESMODHTVPTTTEASVRROIONIVEHPVIODNW ALKEQEDDYEPPPSSALARHLSSLTELARYFRVRVRERNIMSGKSMOERLVPLLTEASVRROIONIVEHPVIODNW PLPTEEN----PGGTPLVRYLEPI--------IRLK-HSLPEGSDVND-----LIKENVKMAVKNVVNSPTIQGAW

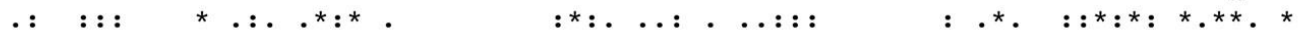

NQKVSPTNGKVNPRVTIHGWVHNTSTGRT

NQRVSPLNGKVNPRVTIHGWIHNLHDNRLFDLNVSVPPPPLNEEKKQSTN EQ---ARKGEFR-EVFVHGWLYDLSTGNIVDLNVTQGPHPFVDDRVPRA:* $\quad$ : *: : * : ***: : : $\quad$.

Figure 1. Multiple sequence alignment of selected $\beta$-carbonic anhydrase ( $\beta$-CAs) from three fungal species. The Cryptococcus neoformans CA (Can2) numbering system was used. Zinc ligands are indicated in red, and amino acids involved in the enzyme catalytic cycle are indicated in blue. Multiple sequence alignment was performed with the program Clustal W, version 2.1. Legend: Malassezia restricta (MreCA), Malassezia globosa (MgCA), and Cryptococcus Neoformans (Can2). Conserved residues are indicated with an asterisk $\left({ }^{*}\right)$, while (:) and (.) indicate conservative and semi-conservative substitutions, respectively. The sequence accession numbers are reported in Table 1.

From the dendrogram reported in Figure 2, MreCA appears to be closely related to the $\beta$-CAs identified in the genome of the other Malassezia species. Intriguingly, the MreCA and MgCA clusters included the $\beta$-CA encoded by the genome of the pathogenic fungus Ustilago maydis, which is responsible for a plant disease known as common corn smut [60]. It has been reported that the genomes of $M$. restricta and globosa encode for many extracellular hydrolases, such as lipases, phospholipases, aspartyl proteases, and acid sphingomyelinases, which are phylogenetically close to those encoded by the $U$. maydis genome [60]. The dendrogram in Figure 2 also shows that the Malassezia $\beta$-CAs are neighbors to the $\beta$-CA from Cryptococcus neoformans (Can2). They are clustered distinctly away from the other $\beta$-CAs found in the genome of fungi, such as Candida albicans, Saccharomyces cerevisiae, Dekkera bruxellensis, Ogataea parapolymorpha, Aspergillus fumigatus, Sordaria macrospora, Trichosporon asahii, and Schizosaccharomyces pombe. This result may be the consequence of a gene duplication event indicating an ancestral $\beta$-CA gene in these two groups of fungi. Furthermore, Malassezia CAs are in the same cluster as the $\beta$-CAs from plants (Figure 2). 


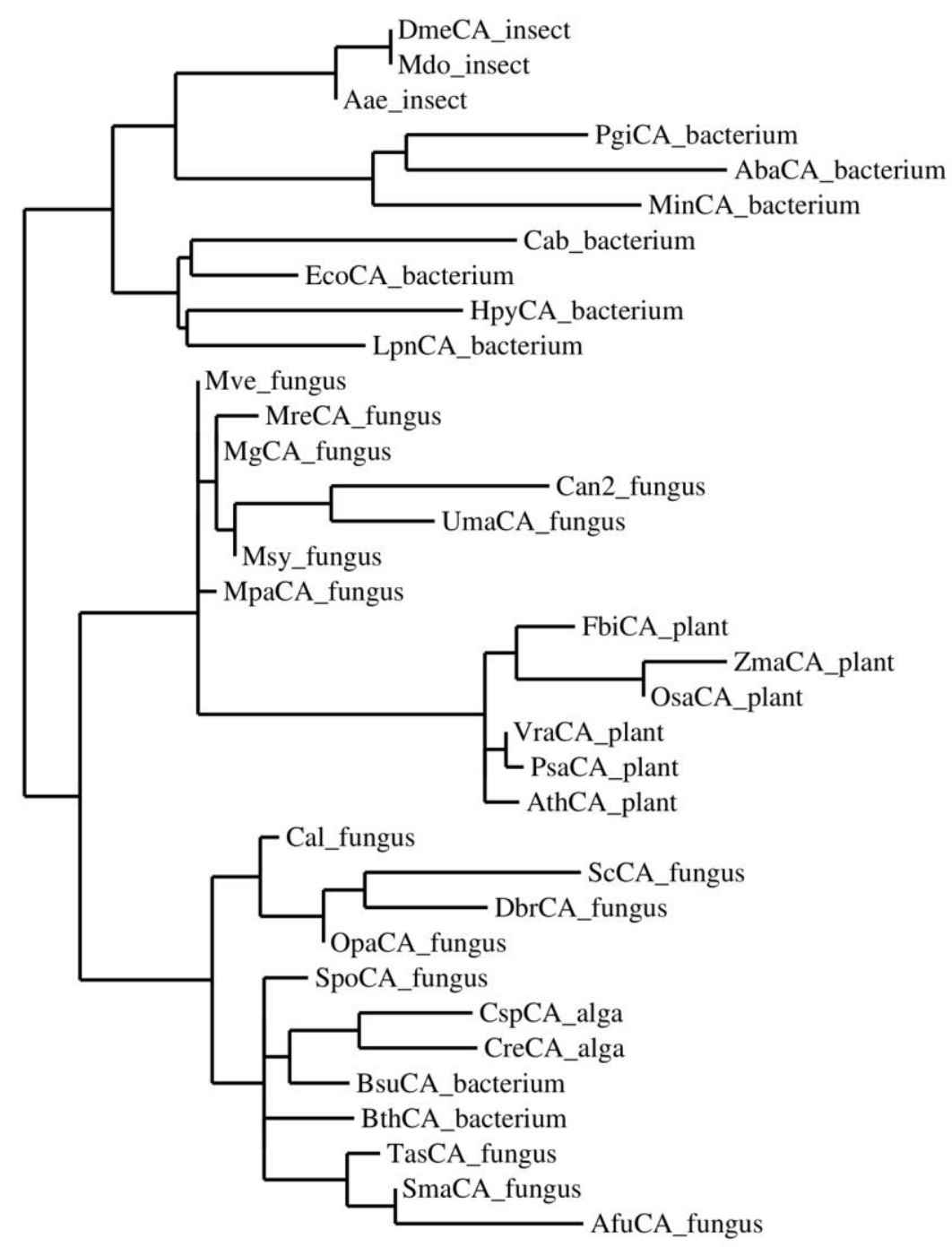

Figure 2. Phylogenetic tree of the $\beta$-CAs from selected prokaryotic and eukaryotic species. The tree was constructed using PhyML 3.0. For the acronyms and organism names see Table 1.

\subsection{Expression, Purification, and Protonography}

IPTG (Isopropyl $\beta$-D-1-thiogalactopyranoside) induction of Escherichia coli BL21 (DE3) cells transformed with the plasmid pET100D-Topo/MreCA resulted in the production of the recombinant $\mathrm{MreCA}$ as a fusion protein containing a His-tag tail at its $\mathrm{N}$-terminus. After sonication and centrifugation, most of the CA activity was recovered in the soluble fraction of the E. coli cell extract. Using an affinity column (His-select HF (High Flow) nickel affinity gel), MreCA was purified to homogeneity, as shown by the appearance of the SDS-PAGE results (material not intended for publication). Samples of the purified MreCA were loaded onto the gel and subjected to protonography to investigate its hydratase activity via SDS-PAGE. Protonography is a powerful technique, which allows the detection of $\mathrm{pH}$ variation on polyacrylamide gel due to the $\mathrm{CA}$-catalyzed conversion of $\mathrm{CO}_{2}$ into bicarbonate and protons $[61,62]$. The production of ions $\left(\mathrm{H}^{+}\right)$during the $\mathrm{CO}_{2}$ hydration reaction can be visualized as a yellow band on the polyacrylamide gel (Figure 3 ). The developed gel is called a protonogram. 


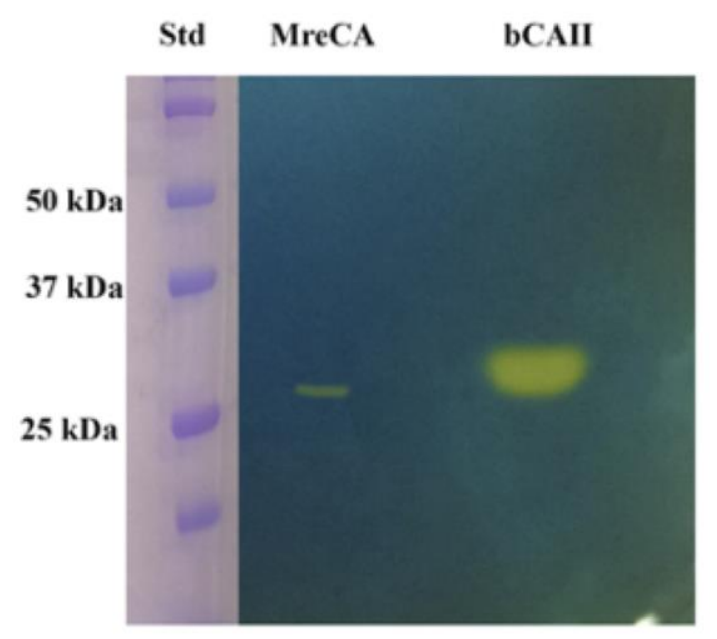

Figure 3. Protonography of MreCA with bovine CA (bCAII) as the standard enzyme.

The MreCA protonogram in Figure 3 shows a band corresponding to a monomer with an apparent molecular weight of about $27.0 \mathrm{kDa}$. The predicted molecular mass of the enzyme fused to the His-tag tail resulting from its amino acid sequence was $27.0 \mathrm{kDa}$. It is interesting to note that, as was found for other CA classes belonging to prokaryotic and eukaryotic organisms, MreCA was able to correctly refold, generating the active enzyme after removing SDS from the gel before developing the protonogram. Commercial bovine CA was used as a positive control.

Table 1. The accession numbers of the $\beta$-CA sequences used in the phylogenetic analysis. Groups, organism names, and acronyms are reported.

\begin{tabular}{|c|c|c|c|}
\hline Group & Organism Name & Acronym & Accession Number \\
\hline \multicolumn{4}{|l|}{ Bacteria } \\
\hline & Porphyromonas gingivalis & PgiCA_bacterium & YP_001929649.1 \\
\hline & Acinetobacter baumannii & AbaCA_bacterium & YP__002326524 \\
\hline & Myroides injenensis & MinCA_bacterium & ZP_10784819 \\
\hline & $\begin{array}{l}\text { Methanobacterium } \\
\text { thermoautotrophicum }\end{array}$ & Cab_bacterium & GI:13786688 \\
\hline & $\begin{array}{l}\text { thermoautotropnicum } \\
\text { Helicobacter pylori }\end{array}$ & HpyCA_bacterium & BAF34127.1 \\
\hline & Legionella pneumophila & LpnCA_bacterium & YP_003619232 \\
\hline & Escherichia coli & EcoCa_bacterium & ACI70660 \\
\hline & Burkholderia thailandensis & BthCA_bacterium & ZP_02386321 \\
\hline & Brucella suis & BsuCA_bacterium & NP_699962.1 \\
\hline \multicolumn{4}{|l|}{ Fungi } \\
\hline & Malassezia globosa & MgCA_fungus & XP_001730815.1 \\
\hline & Malassezia pachydermatis & MpaCA_fungus & XP_017991749.1 \\
\hline & Malassezia vespertilionis & Mve_fungus & PKI85431.1 \\
\hline & Malassezia sympodialis & Msy_fungus & XP_018739548.1 \\
\hline & Malassezia restricta & MreCA_fungus & PRJNA474956 \\
\hline & Cryptococcus neoformans & Can2_fungus & GI:219109194 \\
\hline & Candida albicans & Cal_fungus & XP_721792.1 \\
\hline & Saccharomyces cerevisiae & ScCA_fungus & GAAA26059 \\
\hline & Dekkera bruxellensis & DbrCA_fungus & EFW97556 \\
\hline & Ogataea parapolymorpha & OpaCA_fungus & EFW97556 \\
\hline & Aspergillus fumigatus & AfuCA_fungus & XP_751704 \\
\hline & Sordaria macrospora & SmaCA_fungus & CAT00781 \\
\hline & Trichosporon asahii & TasCA_fungus & EKD04029 \\
\hline & Schizosaccharomyces pombe & SpoCA_fungus & CAA21790 \\
\hline & Ustilago maydis & UmaCA_fungus & XM_011388340.1 \\
\hline
\end{tabular}


Table 1. Cont.

\begin{tabular}{cccc}
\hline Group & Organism Name & Acronym & Accession Number \\
\hline Algae & Coccomyxa sp. & CspCA_alga & AAC33484.1 \\
& Chlamydomonas reinhardtii & CreCA_alga & XP_001699151.1 \\
\hline Insect & & & \\
& Drosophila melanogaster & DmeCA_insect & NP_649849 \\
& Musca domestica & Mdo_insect & XP_005191496.1 \\
& Aedes aegypti & Aae_insect & XP_021707077.1 \\
\hline Plant & & \\
& Vigna radiata & VraCA_plant & AAD27876 \\
& Pisum sativum & PsaCA_plant & AAA33652 \\
& Flaveria bidentis & FbiCA_plant & AAA86939.2 \\
& Arabidopsis thaliana & AthCA_plant & AAA50156 \\
& Zea mays & ZmaCA_plant & NP_001147846.1 \\
& Oryza sativa & OsaCA_plant & AAA86943 \\
\hline
\end{tabular}

\subsection{Determination of the Kinetic Constants}

Using stopped-flow techniques, the kinetic parameters were determined for the purified recombinant MreCA using $\mathrm{CO}_{2}$ as a substrate. The data in Table 2 demonstrate that MreCA shows a catalytic activity higher than that of $\mathrm{MgCA}$, with the following kinetic parameters: $\mathrm{k}_{\text {cat }}$ of $1.06 \times 10^{6} \mathrm{~s}^{-1}$ and $\mathrm{k}_{\mathrm{cat}} / \mathrm{K}_{\mathrm{M}}$ of $1.07 \times 10^{8} \mathrm{M}^{-1} \mathrm{~s}^{-1}$. Therefore, when compared with the high-activity human isoform hCA II, it is only slightly less effective as a catalyst for $\mathrm{CO}_{2}$ hydration. Furthermore, the activity is highly inhibited by acetazolamide, the clinically used sulfonamide inhibitor, with an inhibition constant of $50.7 \mathrm{nM}$, as seen in Table 2. Thus, the two Malassezia enzymes, MgCA and MreCA, show a net difference in their sensitivity to this sulfonamide, with the first one being quite resistant to the inhibitor and the second one being quite sensitive. It is interesting to stress the fact that $\beta$-CAs are missing in the genome of Cutibacterium acnes and Staphylococcus epidermidis, the two most abundant bacteria found on the human scalp. Thus, the synthesis of new drugs capable of interfering with MreCA and MgCA activity will not influence the catalytic mechanism of the CAs encoded by the scalp microbes, preserving not only the integrity of the human skin, but also avoiding interference with human CAs, because the human genome only encodes CAs belonging to the $\alpha$-class.

Table 2. Kinetic parameters for the newly obtained enzyme from MreCA, compared with the human hCA II ( $\alpha$-class) and the $\beta$-class enzyme from MgCA at $25^{\circ} \mathrm{C}, \mathrm{pH} 8.3$ in $20 \mathrm{mM}$ Tris buffer and $20 \mathrm{mM}$ $\mathrm{NaClO}_{4}$, for the $\mathrm{CO}_{2}$ hydration reaction.

\begin{tabular}{ccccc}
\hline Isozyme & $\mathbf{k}_{\mathbf{c a t}}\left(\mathbf{s}^{\mathbf{- 1}}\right)$ & $\mathbf{K}_{\mathbf{M}} \mathbf{( m \mathbf { M } )}$ & $\mathbf{k}_{\mathbf{c a t}} / \mathbf{K}_{\mathbf{M}} \mathbf{( \mathbf { M } ^ { - \mathbf { 1 } } \mathbf { s } ^ { \mathbf { - 1 } } )}$ & $\mathbf{K}_{\mathbf{I}} \mathbf{( A A Z )} \mathbf{( n M )}$ \\
\hline hCA II & $1.4 \times 10^{6}$ & 9.3 & $1.4 \times 10^{8}$ & 12 \\
MgCA & $9.2 \times 10^{5}$ & 11.1 & $8.3 \times 10^{7}$ & 74,000 \\
MreCA * $^{*}$ & $1.06 \times 10^{6}$ & 10.1 & $1.07 \times 10^{8}$ & 50.7 \\
\hline
\end{tabular}

* The kinetic/inhibition parameters are the mean from 3 different assays. Errors are in the range of $10 \%$ of the reported values (material not intended for publication).

\section{Materials and Methods}

\subsection{Cloning and Purification of MreCA}

The genome of $M$. restricta used in this study to retrieve the amino acid sequence was recently published [57]. The amino acid sequence of MreCA is shown in Figure 1. It was back translated into the nucleotide sequence and optimized for codon usage to increase its expression in E. coli cells. The synthetic M. restricta gene, as obtained from GeneArt Company (Milan, Italy), contained four base-pair sequences (CACC) necessary for directional cloning at the $5^{\prime}$ end of the MreCA DNA gene. 
The fragment was cloned into the expression vector pET100/D-TOPO (Invitrogen, Carlsbad, CA, USA), creating the plasmid pET100D-Topo/MreCA. Competent E. coli BL21 (DE3) codon plus cells (Agilent, Santa Clara, CA, USA) were transformed with the pET100D-Topo/MreCA. The level of expression of the target protein was improved by varying the time and temperature of induction and the concentration of the inducer (IPTG). After growth, the cells were harvested and disrupted by sonication at $4{ }^{\circ} \mathrm{C}$ in $20 \mathrm{mM}$ of phosphate buffer, $\mathrm{pH}$ 8.0. Following sonication, the sample was centrifuged at $1200 \times g$ at $4{ }^{\circ} \mathrm{C}$ for $30 \mathrm{~min}$. The supernatant was loaded onto a His-select HF nickel affinity column. The MreCA was eluted with $0.02 \mathrm{M}$ phosphate buffer ( $\mathrm{pH} 8.3$ ) containing $250 \mathrm{mM}$ imidazole and $0.5 \mathrm{M} \mathrm{NaCl}$ at a flow rate of $1.0 \mathrm{~mL} / \mathrm{min}$. Fractions were collected and dialyzed. At this stage of purification, the enzyme was at least $80 \%$ pure, and the obtained recovery was of $0.1 \mathrm{mg}$ of the recombinant MreCA per liter of culture. The catalyst showed activity after undergoing the protonography test $[61,62]$ (Figure 3 ) and via a kinetic, stopped-flow $\mathrm{CO}_{2}$ hydrase assay [63] (Table 2).

\subsection{Protonography}

Wells of $12 \%$ SDS gel were loaded with MreCA or the commercial bovine CA (Sigma, St. Louis, MO, USA), mixed with Laemmli loading buffer containing SDS (1\% final concentration) but without 2-mercaptoethanol. In order to avoid protein denaturation the samples were not boiled. The gel was run at $150 \mathrm{~V}$ until the dye front moved off the gel. Following electrophoresis, the $12 \%$ SDS gel was subjected to protonography in order to detect the MreCA hydratase activity on the gel as described by Capasso et al. [61,62].

\subsection{SDS-PAGE, Primary Structure, and Phylogenetic Analysis}

Sodium dodecyl sulfate (SDS) polyacrylamide gel electrophoresis (PAGE) was performed using $12 \%$ gels as described previously $[61,62,64]$. Multiple amino acid sequence alignment of the amino acid sequences of the $\beta$-CAs from the different species was performed with the program CLUSTAL $W$, version 2.1 [65]. The phylogenetic tree of $\beta$-CAs from the selected prokaryotic and eukaryotic species was constructed by using the program PhyML 3.0 [66].

\subsection{CA Activity Measurements}

An applied photophysics stopped-flow instrument was used for assaying the $\mathrm{CA}$-catalyzed $\mathrm{CO}_{2}$ hydration activity [19]. Bromothymol blue (at a concentration of $0.2 \mathrm{mM}$ ) was used as an indicator, working at the absorbance maximum of $557 \mathrm{~nm}$, with 10-20 mM TRIS (pH 8.3) as a buffer and $20 \mathrm{mM}$ $\mathrm{Na}_{2} \mathrm{SO}_{4}$ for maintaining the ionic strength (this anion is not inhibitory and has a $\mathrm{K}_{\mathrm{I}}>200 \mathrm{mM}$ against this enzyme), following the initial rates of the $\mathrm{CA}$-catalyzed $\mathrm{CO}_{2}$ hydration reaction for a period of 10-100 s. In order to determine the kinetic parameters and inhibition constants, the $\mathrm{CO}_{2}$ concentrations ranged from 1.7 to $17 \mathrm{mM}$. For each measurement, at least six traces of the initial $5 \%-10 \%$ of the reaction were used for determining the initial velocity, working with 10-fold decreasing inhibitor concentrations ranging from $1 \mathrm{nM}$ to $10-100 \mu \mathrm{M}$ (depending on the inhibitor potency, but at least 5 points at different inhibitor concentrations were employed for determining the inhibition constants). The uncatalyzed rates were determined in the same manner and then subtracted from the total observed rates. Stock solutions of inhibitor $(0.1 \mathrm{mM})$ were prepared in distilled-deionized water, and dilutions up to $1 \mathrm{nM}$ were done thereafter with the assay buffer. Inhibitor and enzyme solutions were pre-incubated together for $15 \mathrm{~min}$ at room temperature before assaying, in order to allow for the formation of the E-I complex. The inhibition constants were obtained by non-linear least-squares methods using the Cheng-Prusoff equation, and represent the mean from at least three different determinations. The human isoforms hCA I, II, and IX were assayed in the same conditions as above except that the working $\mathrm{pH}$ was 7.4, using HEPES (4-(2-hydroxyethyl)-1-piperazineethanesulfonic acid) buffer and phenol red as an indicator [63]. All enzymes were recombinant ones produced in our laboratory as described previously [58,59,63,67-70]. 


\subsection{Multiple Sequence Alignment and Phylogenetic Analysis}

Multiple alignment of the amino acid sequences of $\beta$-CAs identified in the genome of organisms belonging to different groups (bacteria, fungi, algae, insects, and plants) was performed with the program CLUSTAL W, version 2.1 [65]. The phylogenetic tree of $\beta$-CAs from the selected prokaryotic and eukaryotic species was constructed using the program PhyML 3.0, which searched for the tree with the highest probability [66].

\section{Conclusions}

We report here on the cloning, purification, and initial characterization of the $\beta$-CA (MreCA) from the genome of the pathogenic fungus $M$. restricta, responsible for dandruff, together with other fungi and bacteria. MreCA has a high catalytic activity for the hydration of $\mathrm{CO}_{2}$ into bicarbonate and protons, with the following kinetic parameters: $\mathrm{k}_{\text {cat }}$ of $1.06 \times 10^{6} \mathrm{~s}^{-1}$ and $\mathrm{k}_{\text {cat }} / \mathrm{K}_{\mathrm{M}}$ of $1.07 \times 10^{8} \mathrm{M}^{-1} \mathrm{~s}^{-1}$. It is also sensitive to inhibition by the classical sulfonamide inhibitor acetazolamide $\left(K_{I}\right.$ of $\left.50.7 \mathrm{nM}\right)$. Phylogenetically, MreCA and other CAs from various Malassezia species seem to be on a different branch, distinct from that of other $\beta$-CAs found in fungi, such as Candida spp., Saccharomyces cerevisiae, Aspergillus fumigatus, and Sordaria macrospora, with only the Cryptococcus neoformans and Ustilago maydis enzymes being on the same branch as MreCA. As previously reported, the closest species were of plant origin. The further characterization of this enzyme and identification of inhibitors that could interfere with its life cycle might constitute new strategies for fighting dandruff and seborrheic dermatitis.

Author Contributions: S.D.P., performed the cloning, expression, and purification of the recombinant coral enzyme; D.V. performed the enzyme kinetic and all the inhibition assays; C.G., J.H., and X.M. contributed reagents and materials; C.C. (Cécile Clavaud) analyzed the data and edited the manuscript; and C.T.S. and C.C. (Clemente Capasso) wrote, edited, and supervised the manuscript.

Funding: The research was entirely funded by L'Oréal Research \& Innovation.

Conflicts of Interest: The authors declare no conflicts of interest.

\section{References}

1. Alterio, V.; Di Fiore, A.; D’Ambrosio, K.; Supuran, C.T.; De Simone, G. Multiple binding modes of inhibitors to carbonic anhydrases: How to design specific drugs targeting 15 different isoforms? Chem. Rev. 2012, 112, 4421-4468. [CrossRef]

2. Berrino, E.; Supuran, C.T. Novel approaches for designing drugs that interfere with pH regulation. Expert Opin. Drug Discov. 2019, 14, 231-248. [CrossRef] [PubMed]

3. Capasso, C.; Supuran, C.T. An overview of the alpha-, beta- and gamma-carbonic anhydrases from Bacteria: Can bacterial carbonic anhydrases shed new light on evolution of bacteria? J. Enzyme Inhib. Med. Chem. 2015, 30, 325-332. [CrossRef]

4. Capasso, C.; Supuran, C.T. Bacterial Carbonic Anhydrases, in Zinc Enzyme Inhibitors. Top. Med. Chem. 2017, $1,134-152$.

5. Capasso, C.; Supuran, C.T. Protozoan carbonic anhydrases, in Zinc Enzyme Inhibitors. Top. Med. Chem. 2017, 1,111-133.

6. Neri, D.; Supuran, C.T. Interfering with $\mathrm{pH}$ regulation in tumours as a therapeutic strategy. Nat. Rev. Drug Discov. 2011, 10, 767-777. [CrossRef] [PubMed]

7. Ozensoy Guler, O.; Capasso, C.; Supuran, C.T. A magnificent enzyme superfamily: Carbonic anhydrases, their purification and characterization. J. Enzyme Inhib. Med. Chem. 2016, 31, 689-694. [CrossRef]

8. Supuran, C.T. Carbonic anhydrases: Novel therapeutic applications for inhibitors and activators. Nat. Rev. Drug Discov. 2008, 7, 168-181. [CrossRef]

9. Supuran, C.T. Carbonic anhydrases: From biomedical applications of the inhibitors and activators to biotechnological use for $\mathrm{CO}(2)$ capture. J. Enzyme Inhib. Med. Chem. 2013, 28, 229-230. [CrossRef] [PubMed]

10. Supuran, C.T. Structure and function of carbonic anhydrases. Biochem. J. 2016, 473, 2023-2032. [CrossRef]

11. Supuran, C.T. How many carbonic anhydrase inhibition mechanisms exist? J. Enzyme Inhib. Med. Chem. 2016, 31, 345-360. [CrossRef] [PubMed] 
12. Supuran, C.T. Advances in structure-based drug discovery of carbonic anhydrase inhibitors. Expert Opin. Drug Discov. 2017, 12, 61-88. [CrossRef]

13. Supuran, C.T. Carbonic Anhydrases and Metabolism. Metabolites 2018, 8, 25. [CrossRef]

14. Supuran, C.T. Carbonic anhydrase inhibitors and their potential in a range of therapeutic areas. Expert Opin. Ther. Pat. 2018, 28, 709-712. [CrossRef] [PubMed]

15. Supuran, C.T. Applications of carbonic anhydrases inhibitors in renal and central nervous system diseases. Expert Opin. Ther. Pat. 2018, 28, 713-721. [CrossRef]

16. Supuran, C.T.; Capasso, C. Biomedical applications of prokaryotic carbonic anhydrases. Expert Opin. Ther. Pat. 2018, 28, 745-754. [CrossRef] [PubMed]

17. Supuran, C.T.; Vullo, D.; Manole, G.; Casini, A.; Scozzafava, A. Designing of novel carbonic anhydrase inhibitors and activators. Curr. Med. Chem. Cardiovasc. Hematol. Agents 2004, 2, 49-68. [CrossRef]

18. Supuran, C.T. Carbonic Anhydrase Inhibition and the Management of Hypoxic Tumors. Metabolites 2017, 7, 48. [CrossRef]

19. Supuran, C.T. Carbon-versus sulphur-based zinc binding groups for carbonic anhydrase inhibitors? J. Enzyme Inhib. Med. Chem. 2018, 33, 485-495. [CrossRef]

20. Supuran, C.T. Carbonic anhydrase inhibitors as emerging agents for the treatment and imaging of hypoxic tumors. Expert Opin. Investig. Drugs 2018, 27, 963-970. [CrossRef] [PubMed]

21. Nocentini, A.; Supuran, C.T. Carbonic anhydrase inhibitors as antitumor/antimetastatic agents: A patent review (2008-2018). Expert Opin. Ther. Pat. 2018, 28, 729-740. [CrossRef]

22. Nishimori, I.; Minakuchi, T.; Maresca, A.; Carta, F.; Scozzafava, A.; Supuran, C.T. The beta-carbonic anhydrases from Mycobacterium tuberculosis as drug targets. Curr. Pharm. Des. 2010, 16, 3300-3309. [CrossRef]

23. Nishimori, I.; Minakuchi, T.; Vullo, D.; Scozzafava, A.; Innocenti, A.; Supuran, C.T. Carbonic anhydrase inhibitors. Cloning, characterization, and inhibition studies of a new beta-carbonic anhydrase from Mycobacterium tuberculosis. J. Med. Chem. 2009, 52, 3116-3120. [CrossRef]

24. Guzel, O.; Maresca, A.; Scozzafava, A.; Salman, A.; Balaban, A.T.; Supuran, C.T. Discovery of low nanomolar and subnanomolar inhibitors of the mycobacterial beta-carbonic anhydrases Rv1284 and Rv3273. J. Med. Chem. 2009, 52, 4063-4067. [CrossRef]

25. Del Prete, S.; Isik, S.; Vullo, D.; De Luca, V.; Carginale, V.; Scozzafava, A.; Supuran, C.T.; Capasso, C. DNA cloning, characterization, and inhibition studies of an alpha-carbonic anhydrase from the pathogenic bacterium Vibrio cholerae. J. Med. Chem. 2012, 55, 10742-10748. [CrossRef] [PubMed]

26. Del Prete, S.; Vullo, D.; De Luca, V.; Carginale, V.; di Fonzo, P.; Osman, S.M.; AlOthman, Z.; Supuran, C.T.; Capasso, C. Anion inhibition profiles of alpha-, beta- and gamma-carbonic anhydrases from the pathogenic bacterium Vibrio cholerae. Bioorg. Med. Chem. 2016, 24, 3413-3417. [CrossRef] [PubMed]

27. Del Prete, S.; Vullo, D.; De Luca, V.; Carginale, V.; Osman, S.M.; AlOthman, Z.; Supuran, C.T.; Capasso, C. Comparison of the sulfonamide inhibition profiles of the alpha-, beta- and gamma-carbonic anhydrases from the pathogenic bacterium Vibrio cholerae. Bioorg. Med. Chem. Lett. 2016, 26, 1941-1946. [CrossRef] [PubMed]

28. Ferraroni, M.; Del Prete, S.; Vullo, D.; Capasso, C.; Supuran, C.T. Crystal structure and kinetic studies of a tetrameric type II beta-carbonic anhydrase from the pathogenic bacterium Vibrio cholerae. Acta Crystallogr. D Biol. Crystallogr. 2015, 71, 2449-2456. [CrossRef]

29. Nishimori, I.; Onishi, S.; Takeuchi, H.; Supuran, C.T. The alpha and beta classes carbonic anhydrases from Helicobacter pylori as novel drug targets. Curr. Pharm. Des. 2008, 14, 622-630.

30. Capasso, C.; Supuran, C.T. Bacterial, fungal and protozoan carbonic anhydrases as drug targets. Expert Opin. Ther. Targets 2015, 19, 1689-1704. [CrossRef]

31. Capasso, C.; Supuran, C.T. An Overview of the Selectivity and Efficiency of the Bacterial Carbonic Anhydrase Inhibitors. Curr. Med. Chem. 2015, 22, 2130-2139. [CrossRef]

32. Annunziato, G.; Giovati, L.; Angeli, A.; Pavone, M.; Del Prete, S.; Pieroni, M.; Capasso, C.; Bruno, A.; Conti, S.; Magliani, W.; et al. Discovering a new class of antifungal agents that selectively inhibits microbial carbonic anhydrases. J. Enzyme Inhib. Med. Chem. 2018, 33, 1537-1544. [CrossRef] 
33. Guzel-Akdemir, O.; Angeli, A.; Demir, K.; Supuran, C.T.; Akdemir, A. Novel thiazolidinone-containing compounds, without the well-known sulphonamide zinc-binding group acting as human carbonic anhydrase IX inhibitors. J. Enzyme Inhib. Med. Chem. 2018, 33, 1299-1308. [CrossRef]

34. Murray, A.B.; Aggarwal, M.; Pinard, M.; Vullo, D.; Patrauchan, M.; Supuran, C.T.; McKenna, R. Structural Mapping of Anion Inhibitors to beta-Carbonic Anhydrase psCA3 from Pseudomonas aeruginosa. ChemMedChem 2018, 13, 2024-2029. [CrossRef]

35. Nocentini, A.; Cadoni, R.; Dumy, P.; Supuran, C.T.; Winum, J.-Y. Carbonic anhydrases from Trypanosoma cruzi and Leishmania donovani chagasi are inhibited by benzoxaboroles. J. Enzyme Inhib. Med. Chem. 2018, 33, 286-289. [CrossRef]

36. Supuran, C.T. Inhibition of carbonic anhydrase from Trypanosoma cruzi for the management of Chagas disease: An underexplored therapeutic opportunity. Future Med. Chem. 2016, 8, 311-324. [CrossRef]

37. Vermelho, A.B.; da Silva Cardoso, V.; Ricci Junior, E.; Dos Santos, E.P.; Supuran, C.T. Nanoemulsions of sulfonamide carbonic anhydrase inhibitors strongly inhibit the growth of Trypanosoma cruzi. J. Enzyme Inhib. Med. Chem. 2018, 33, 139-146. [CrossRef]

38. Del Prete, S.; De Luca, V.; Vullo, D.; Osman, S.M.; AlOthman, Z.; Carginale, V.; Supuran, C.T.; Capasso, C. A new procedure for the cloning, expression and purification of the beta-carbonic anhydrase from the pathogenic yeast Malassezia globosa, an anti-dandruff drug target. J. Enzyme Inhib. Med. Chem. 2016, 31, 1156-1161. [CrossRef]

39. Nocentini, A.; Vullo, D.; Del Prete, S.; Osman, S.M.; Alasmary, F.A.S.; AlOthman, Z.; Capasso, C.; Carta, F.; Gratteri, P.; Supuran, C.T. Inhibition of the beta-carbonic anhydrase from the dandruff-producing fungus Malassezia globosa with monothiocarbamates. J. Enzyme Inhib. Med. Chem. 2017, 32, 1064-1070. [CrossRef]

40. Nocentini, A.; Bua, S.; Del Prete, S.; Heravi, Y.E.; Saboury, A.A.; Karioti, A.; Bilia, A.R.; Capasso, C.; Gratteri, P.; Supuran, C.T. Natural Polyphenols Selectively Inhibit beta-Carbonic Anhydrase from the Dandruff-Producing Fungus Malassezia globosa: Activity and Modeling Studies. ChemMedChem 2018, 13, 816-823. [CrossRef]

41. Hewitson, K.S.; Vullo, D.; Scozzafava, A.; Mastrolorenzo, A.; Supuran, C.T. Molecular cloning, characterization, and inhibition studies of a beta-carbonic anhydrase from Malassezia globosa, a potential antidandruff target. J. Med. Chem. 2012, 55, 3513-3520. [CrossRef]

42. Singh, S.; Supuran, C.T. In silico modeling of beta-carbonic anhydrase inhibitors from the fungus Malassezia globosa as antidandruff agents. J. Enzyme Inhib. Med. Chem. 2016, 31, 417-424.

43. Del Prete, S.; Vullo, D.; Osman, S.M.; AlOthman, Z.; Capasso, C.; Supuran, C.T. Anion inhibition studies of the dandruff-producing fungus Malassezia globosa beta-carbonic anhydrase MgCA. Bioorg. Med. Chem. Lett. 2015, 25, 5194-5198. [CrossRef]

44. Vullo, D.; Del Prete, S.; Nocentini, A.; Osman, S.M.; AlOthman, Z.; Capasso, C.; Bozdag, M.; Carta, F.; Gratteri, P.; Supuran, C.T. Dithiocarbamates effectively inhibit the beta-carbonic anhydrase from the dandruff-producing fungus Malassezia globosa. Bioorg. Med. Chem. 2017, 25, 1260-1265. [CrossRef]

45. Entezari Heravi, Y.; Bua, S.; Nocentini, A.; Del Prete, S.; Saboury, A.A.; Sereshti, H.; Capasso, C.; Gratteri, P.; Supuran, C.T. Inhibition of Malassezia globosa carbonic anhydrase with phenols. Bioorg. Med. Chem. 2017, 25, 2577-2582. [CrossRef]

46. Angiolella, L.; Carradori, S.; Maccallini, C.; Giusiano, G.; Supuran, C.T. Targeting Malassezia species for Novel Synthetic and Natural Antidandruff Agents. Curr. Med. Chem. 2017, 24, 2392-2412. [CrossRef] [PubMed]

47. Nocentini, A.; Cadoni, R.; Del Prete, S.; Capasso, C.; Dumy, P.; Gratteri, P.; Supuran, C.T.; Winum, J.-Y. Benzoxaboroles as Efficient Inhibitors of the beta-Carbonic Anhydrases from Pathogenic Fungi: Activity and Modeling Study. ACS Med. Chem. Lett. 2017, 8, 1194-1198. [CrossRef]

48. Bua, S.; Osman, S.M.; AlOthman, Z.; Supuran, C.T.; Nocentini, A. Benzenesulfonamides incorporating nitrogenous bases show effective inhibition of beta-carbonic anhydrases from the pathogenic fungi Cryptococcus neoformans, Candida glabrata and Malassezia globosa. Bioorg. Chem. 2019, 86, 39-43. [CrossRef] [PubMed]

49. Angeli, A.; Pinteala, M.; Maier, S.S.; Del Prete, S.; Capasso, C.; Simionescu, B.C.; Supuran, C.T. Inhibition of alpha-, beta-, gamma-, delta-, zeta- and eta-class carbonic anhydrases from bacteria, fungi, algae, diatoms and protozoans with famotidine. J. Enzyme Inhib. Med. Chem. 2019, 34, 644-650. [CrossRef] [PubMed] 
50. Clavaud, C.; Jourdain, R.; Bar-Hen, A.; Tichit, M.; Bouchier, C.; Pouradier, F.; El Rawadi, C.; Guillot, J.; Menard-Szczebara, F.; Breton, L.; et al. Dandruff is associated with disequilibrium in the proportion of the major bacterial and fungal populations colonizing the scalp. PLoS ONE 2013, 8, e58203. [CrossRef]

51. Stalhberger, T.; Simenel, C.; Clavaud, C.; Eijsink, V.G.H.; Jourdain, R.; Delepierre, M.; Latge, J.-P.; Breton, L.; Fontaine, T. Chemical organization of the cell wall polysaccharide core of Malassezia restricta. J. Biol. Chem. 2014, 289, 12647-12656. [CrossRef] [PubMed]

52. Wang, L.; Clavaud, C.; Bar-Hen, A.; Cui, M.; Gao, J.; Liu, Y.; Liu, C.; Shibagaki, N.; Gueniche, A.; Jourdain, R.; et al. Characterization of the major bacterial-fungal populations colonizing dandruff scalps in Shanghai, China, shows microbial disequilibrium. Exp. Dermatol. 2015, 24, 398-400. [CrossRef] [PubMed]

53. Grice, E.A.; Dawson, T.L.J. Host-microbe interactions: Malassezia and human skin. Curr. Opin. Microbiol. 2017, 40, 81-87. [CrossRef] [PubMed]

54. Park, T.; Kim, H.-J.; Myeong, N.R.; Lee, H.G.; Kwack, I.; Lee, J.; Kim, B.J.; Sul, W.J.; An, S. Collapse of human scalp microbiome network in dandruff and seborrhoeic dermatitis. Exp. Dermatol. 2017, 26, 835-838. [CrossRef] [PubMed]

55. Theelen, B.; Cafarchia, C.; Gaitanis, G.; Bassukas, I.D.; Boekhout, T.; Dawson, T.L. Corrigendum: Malassezia ecology, pathophysiology, and treatment. Med. Mycol. 2019, 57, e2. [CrossRef] [PubMed]

56. Xu, Z.; Wang, Z.; Yuan, C.; Liu, X.; Yang, F.; Wang, T.; Wang, J.; Manabe, K.; Qin, O.; Wang, X.; et al. Dandruff is associated with the conjoined interactions between host and microorganisms. Sci. Rep. 2016, 6, 24877. [CrossRef] [PubMed]

57. Morand, S.C.; Bertignac, M.; Iltis, A.; Kolder, I.C.R.M.; Pirovano, W.; Jourdain, R.; Clavaud, C. Complete Genome Sequence of Malassezia restricta CBS 7877, an Opportunist Pathogen Involved in Dandruff and Seborrheic Dermatitis. Microbiol. Resour. Announc. 2019, 8, e01543-18. [CrossRef]

58. Schlicker, C.; Hall, R.A.; Vullo, D.; Middelhaufe, S.; Gertz, M.; Supuran, C.T.; Muhlschlegel, F.A.; Steegborn, C. Structure and inhibition of the $\mathrm{CO}_{2}$-sensing carbonic anhydrase Can2 from the pathogenic fungus Cryptococcus neoformans. J. Mol. Biol. 2009, 385, 1207-1220. [CrossRef]

59. Innocenti, A.; Muhlschlegel, F.A.; Hall, R.A.; Steegborn, C.; Scozzafava, A.; Supuran, C.T. Carbonic anhydrase inhibitors: Inhibition of the beta-class enzymes from the fungal pathogens Candida albicans and Cryptococcus neoformans with simple anions. Bioorg. Med. Chem. Lett. 2008, 18, 5066-5070. [CrossRef]

60. Xu, J.; Saunders, C.W.; Hu, P.; Grant, R.A.; Boekhout, T.; Kuramae, E.E.; Kronstad, J.W.; Deangelis, Y.M.; Reeder, N.L.; Johnstone, K.R.; et al. Dandruff-associated Malassezia genomes reveal convergent and divergent virulence traits shared with plant and human fungal pathogens. Proc. Natl. Acad. Sci. USA 2007, 104, 18730-18735. [CrossRef]

61. De Luca, V.; Del Prete, S.; Supuran, C.T.; Capasso, C. Protonography, a new technique for the analysis of carbonic anhydrase activity. J. Enzyme Inhib. Med. Chem. 2015, 30, 277-282. [CrossRef]

62. Del Prete, S.; De Luca, V.; Supuran, C.T.; Capasso, C. Protonography, a technique applicable for the analysis of eta-carbonic anhydrase activity. J. Enzyme Inhib. Med. Chem. 2015, 30, 920-924. [CrossRef]

63. Khalifah, R.G. The carbon dioxide hydration activity of carbonic anhydrase. I. Stop-flow kinetic studies on the native human isoenzymes B and C. J. Biol. Chem. 1971, 246, 2561-2573.

64. Laemmli, U.K. Cleavage of structural proteins during the assembly of the head of bacteriophage T4. Nature 1970, 227, 680-685. [CrossRef]

65. Larkin, M.A.; Blackshields, G.; Brown, N.P.; Chenna, R.; McGettigan, P.A.; McWilliam, H.; Valentin, F.; Wallace, I.M.; Wilm, A.; Lopez, R.; et al. Clustal W and Clustal X version 2.0. Bioinformatics 2007, 23, 2947-2948. [CrossRef] [PubMed]

66. Guindon, S.; Dufayard, J.-F.; Lefort, V.; Anisimova, M.; Hordijk, W.; Gascuel, O. New algorithms and methods to estimate maximum-likelihood phylogenies: Assessing the performance of PhyML 3.0. Syst. Biol. 2010, 59, 307-321. [CrossRef] [PubMed]

67. Carta, F.; Scozzafava, A.; Supuran, C.T. Sulfonamides: A patent review (2008-2012). Expert Opin. Ther. Pat. 2012, 22, 747-758. [CrossRef] [PubMed]

68. Pastorekova, S.; Casini, A.; Scozzafava, A.; Vullo, D.; Pastorek, J.; Supuran, C.T. Carbonic anhydrase inhibitors: The first selective, membrane-impermeant inhibitors targeting the tumor-associated isozyme IX. Bioorg. Med. Chem. Lett. 2004, 14, 869-873. [CrossRef] 
69. Scozzafava, A.; Carta, F.; Supuran, C.T. Secondary and tertiary sulfonamides: A patent review (2008-2012). Expert Opin. Ther. Pat. 2013, 23, 203-213. [CrossRef] [PubMed]

70. Supuran, C.T. Carbonic anhydrase inhibitors as emerging drugs for the treatment of obesity. Expert Opin. Emerg. Drugs 2012, 17, 11-15. [CrossRef]

(c) (

(C) 2019 by the authors. Licensee MDPI, Basel, Switzerland. This article is an open access article distributed under the terms and conditions of the Creative Commons Attribution (CC BY) license (http://creativecommons.org/licenses/by/4.0/). 